\title{
EATING OUT AND IN BETWEEN: OBSERVATIONS FROM THE POP-UP RESTAURANT SCENE IN ESTONIA
}

\author{
Ester Bardone \\ Lecturer \\ Department of Ethnology, Institute of Cultural Research \\ University of Tartu, Estonia \\ e-mail:ester.bardone@ut.ee
}

\author{
Anu Kannike \\ Senior Research Fellow \\ Estonian National Museum, Estonia \\ e-mail:anu.kannike@erm.ee
}

\begin{abstract}
The article focuses on a particular form of consumption in contemporary culture - pop-up restaurants - from the ethnological viewpoint, drawing on our on-going research in Estonia. We trace the emergence of a new phenomenon over the past couple of years, examining a variety of temporary food establishments in urban as well as rural settings. As Estonian food culture is becoming more and more hybrid, pop-ups reflect global trends in the gourmet foodscape - an increased attention to environmental consciousness, local specialities and authentic experiences as opposed to industrial or mainstream restaurant food. The analysis aims to examine how pop-up restaurants challenge borders between private and public, business and entertainment. Creative and experimental practices of lifestyle entrepreneurs and reflective consumers in such temporary restaurants create new liminal spaces where innovative ideas about food, the home, and community are negotiated. By extending the borders of the conventional restaurant or the home into public space, the pop-up restaurants create spaces of negotiation between the private and the public and new forms of commensality.
\end{abstract}

Keywords: festivals, food culture, local communities, pop-up cafés, restaurants

\section{INTRODUCTION: THE POP-UP PHENOMENON}

In contemporary Western society a new phenomenon in food culture - the pop-up restaurant - challenges the borders between private and public consumption. This article traces the emergence of this phenomenon in Estonia in 
2011-2014, examining a variety of temporary food establishments in urban as well as rural settings.

A number of recent studies have argued for regarding consumption as a spatial activity. Increasingly transient and mobile lifestyles and new technologies have resulted in diverse novel uses of public space. Temporary venues for consumption have been among the most common manifestations of this phenomenon in recent years. Pop-ups are micro-events that are put up at the kind of venues where people "collect as many experiences as possible" (Fernandes \& Sharma 2013). Thus the pop-up phenomenon is closely related to the ideologies of the "experience economy", which advocate business services to create "experiencescapes" in order to engage clients' senses and to surprise them with novel settings and ideas (Pine \& Gilmore 1999; Jönsson 2002; Löfgren \& Willim 2005). There is a growing range of public and private spaces catering for the needs of the "time-starved consumer on the move" (Bishop \& Williams 2012: 68). Many pop-up shops, restaurants, performances, etc. reflect the hybrid nature of culture, and "explicitly offer new consumer experiences by blurring the usual boundaries between eating, theatre, music and art" (Bishop \& Williams 2012: 213). More and more people work in a flexible manner both in terms of location and time (part-time jobs, home enterprises, etc.) and take up self-employment or a temporary project in addition to or instead of their present occupation as a lifestyle choice. The actors of temporary phenomena are increasingly multidisciplinary.

The pop-up phenomenon points to the blurring boundaries between public and private, professional and amateur, business and leisure, concerning the use of both space and time. Especially the border between the private and the public becomes increasingly ambiguous in pop-up events, giving rise to "states of liminality" (Zukin 1991). As we know from anthropological research, liminal practices are distinct from the routines and rules of everyday life, creating inbetweenness in a spatial, social or cultural sense (see Rapport \& Overing 2000: 229-236). Sharon Zukin argues that liminal space is a growing characteristic of the contemporary city in which localism, or neighbourhood urbanism, has been transformed into postmodern transitional space. Liminal spaces are ambiguous and ambivalent, they slip between global market and local place, between public use and private value, between work and home, between commerce and culture (Zukin 1991: 222).

By examining four different cases of pop-up restaurants in Estonia, this article aims to give an overview of the emerging landscape of temporary eating establishments in Estonia and study how the innovative practices of entrepreneurs challenge borders between private and public, business and entertainment, giving rise to new liminal spaces in urban and rural settings. 


\section{THE POP-UP RESTAURANT}

In this study the term 'restaurant' is used in a broad sense, not just as an enterprise where food is prepared by professional cooks, but as a public eating place, including temporary cafés, pubs, bars, etc. The pop-up restaurants, sometimes also called supper clubs, ${ }^{1}$ are temporary eating establishments that may operate from a private home, although equally they may emerge in varied locations in public space (especially in bigger cities) and in festival settings. Historically the temporary geography of food consumption has existed in the form of, for instance, street food markets. However, in the case of the pop-up restaurant one may say that the temporary use is not just an instrumental but also an aesthetic decision - the performance of dining may redefine the everyday meanings of the social space used at different levels (cf. Harris 2014). The temporary performances enacted in pop-up restaurants likewise fit into the experience economy schema as they create transitory spaces for new affective experiences that emerge from various forms of interaction and participation. The latter, in turn, challenge the habitual borders between the private and public in the restaurant scene (cf. Noorani \& Blencowe \& Brigstocke 2013: 115).

The pop-up dining concept has been developed in various ways, extending the conventional restaurant/café experience into streets, parks, museums, shops, art galleries, private living rooms and gardens. Sometimes it may take the form of "guerrilla hospitality", leading to the emergence of pop-up venues in dilapidated buildings and ruins in cities (see Lugosi, P. \& Bell \& Lugosi, K. 2010). Underground pop-up restaurants became popular in Great Britain and Australia in the first decade of the twenty-first century but actually existed well before in the United States and Cuba. The British pop-up restaurant scene is described as follows:

Occurring in unusual places - an abandoned shop, a boathouse, a garden or a hired location - it is 'pop-up' because it is temporary, either in terms of the space or the amount of time it will remain open. Frequently the chefs are professionals and the waiting staff experienced. Prices tend to be higher. But it is a great opportunity for young chefs without their own restaurants to showcase their food. (Rodgers 2011: 18)

Thus, a pop-up restaurant may also be a kind of start-up for young professionals to gain exposure for their skills in the field of hospitality as they seek investors and attention pursuant to opening a restaurant or another culinary establishment.

Pop-up dining is likewise a good example of how lines between public and domestic spaces become blurred. In many cases pop-up restaurants operate 
in a private home, garden or as an extension of the domestic space into the street. They may be legal, semi-legal or even illegal. Supper clubs, also characterised as "paid dinner parties" (Williams 2009) held in private homes, are attractive among foodies because they are anarchic and adventurous and at the same time based on mutual trust. Supper clubs provide intimate encounters in somebody's private space while being at the same time social events where guests can interact and share their love for food and thirst for the new (Tyler 2009). Furthermore, novel forms of domesticity and hospitality are emerging in contemporary culture, which are looking for authentic tastes and at the same time intimacy that is often lost in anonymous urban consumption (Russo 2012).

Additionally, the virtual space of the new media, especially social media (for example weblogs, Facebook), has facilitated the development of the popup restaurant movement. The information can be spread quickly, yet among selected people, and no investment in advertising is required, giving amateur cooks the chance to enter a scene that was previously occupied by professionals (de Solier 2013). Thus, the pop-up phenomenon may also be related to the democratisation of contemporary foodscapes in which consumers want to actively participate in making their food and sharing it with others in settings alternative to traditional restaurants (Johnston \& Baumann 2010).

In Estonia the term 'pop-up' was taken into use relatively recently, mostly in connection with temporary design and fashion shops, and cafés, mainly of alternative or charitable character. ${ }^{2}$ However, from the academic viewpoint the local pop-up phenomenon has been discussed briefly, mainly in the context of temporary urbanism / urban architecture (Kurik 2013). Although temporary eating establishments in public or domestic spaces are not a new phenomenon in Estonia (for example, at traditional fairs, markets or streets), the idea and concept of the pop-up restaurant arrived here just a few years ago.

We aim to discuss some aspects of pop-up restaurants as a multifaceted phenomenon, trying to outline novel features of these establishments in the context of Estonian food culture and the ways pop-up restaurants are positioned in the ambivalent zone between the private and the public. We mainly focus on activities of the hosts of the restaurants and their services. Through participant observation and in-depth semi-structured interviews (from 2011 to 2014) we established a personal rapport with people responsible for various pop-up establishments and aimed to pinpoint the motives, visions, and practices of the restaurateurs. Due to the limited character of these restaurants both in time and space: once a year in Kärdla on Hiiumaa Island), irregularly in Uus Maailm (New World, a subdistrict in Tallinn), approximately once a month in the case of the Tallinn Supper Club, and from a couple of times a month to several times a week in the case of Ööbiku Gastronomy Farm in Rapla County (depending on the season and visitor interest), short-term fieldwork was inevitable. Yet, in 
all cases (except in the case of Kärdla) it involved several visits: first as clients documenting the overall atmosphere of the event, the specific setting, menu, and communication patterns of the establishment, and introducing our aims to the hosts, and, secondly, for interviews. Apart from the interviews and fieldwork observations, we used as our sources websites and Facebook accounts, weblogs as well as texts and photographs in the printed press. Although the feedback from the customers of pop-up restaurants is of great analytical importance, it remained beyond the scope of this study, as it would have required different methods for data collection and analysis.

\section{KÄRDLA CAFÉ DAY}

Food festivals have been an essential ingredient of culinary tourism as well as destination branding. In recent years pop-up cafés and other temporary eating establishments have become increasingly popular as part of tourism destination marketing as well as an expression of urban vernacular creativity that enables individuals to re-design the use and meaning of public space. The Kärdla Café Day, organised annually since 2007, is the oldest and best-known pop-up food event in Estonia. In recent years it has become one of the top summer festivals, attracting huge crowds of visitors, mostly tourists from the mainland. In the centre of this small island of 8000 inhabitants, "the host of a small café has to calculate upon a thousand guests per day, and that of a medium-sized café - two or three thousand" (Rudi 2013). It is also the largest pop-up event in Estonia in terms of space, totally transforming the habitual patterns of movement, communication, and consumption in the township's streets, parks, the seaside, and private gardens. Recently, the café day has extended over the whole island with pre- and after-cafés (cafés on the day before and after the main event) in different villages, ports or museums.

The event was initially seen by the organisers as a revitalisation of a local tradition: workers from the Kärdla Textile Factory were among the first Estonians to start coffee drinking regularly in the mid-nineteenth century; the fashion spread quickly and the people of Kärdla became known as "coffee pots" (kohvilähkrid) (see Kohvilähkrid). On the first café day sixteen cafés were set up in private gardens and public places not related to dining (the city government building, the church, the museum, the port). Project leader Ere Naat described the event as a "café farce" that would enable people to "take a look at the strata of history and culture of Kärdla through the tradition of "coffee pots"' (Pulk 2007).

First set up by the local tourism organisation and now by the Kärdla Café Day NGO, it has merged the promotion of the island as a tourist destination 
with the spread of knowledge of local history and traditions. Helgi Põllo, research director of the Hiiumaa Museum and history counsellor to the event, states that it is "a conscious valuation of traditions and cultural heritage" alongside other analogous enterprises, such as folklore festivals, village days, etc., thereby contributing to "the strength and sustainability of the identity of the community" (Põllo 2010).

The event has a permanent organisation committee which chooses about fifteen entrepreneurs, NGOs or just families or groups of friends from among the many applicants to set up a temporary café. All the cafés are supposed to have a theme reflected in the menu, decoration, and entertainment programme. Some themes only occur once, while others run through the ten-year history of the event, like cafés in historical or nostalgic styles that have an educational component: The Barons' Veranda, displaying a nineteenth-century noble atmosphere, is decorated like a century-old classroom, some cafés resemble a village tavern or even a Soviet-style bus station. Another permanent theme is that of the sea, coastal life, and the Baltic Sea region. Living on the island is supposed not only to shape the lifestyle, but also the mindset of the Hiiumaa people. Openness to foreign influence, hospitality and flexibility, as well as living "in accordance to the rhythms of nature" are values associated with the islanders and are considered worthy of preservation according to local cultural leaders (Põllo \& Kokovkin 2007). Caring about the community and one's neighbours is also a part of the Kärdla Café Day ideology: a number of cafés have supported charities or communal projects (the local hospital, youth centre, people with special needs, renovation of a historical lighthouse, etc.) (see in detail: Hiiumaa kohvikutepäevad; Kärdla kohvikutepäev).

Over the years the Kärdla Café Day has transformed from an improvised local event consisting of home cafés into a large festival orchestrated to promote not only Kärdla, but the whole island as a tourist destination. The pompous opening ceremony is now held in the main square and on several occasions the former president of Estonia, Toomas Hendrik Ilves, opened the event as a guest of honour. The comparison of the names and programmes of the pop-up cafés over the years reveals a turn towards more cosmopolitan and trendy menus and a shift from traditional cafés and restaurants towards multi-dimensional performance arenas with concerts, workshops, children's events, TV and radio broadcasts, and so on. Another noticeable tendency that emerged some years ago is the increasing localisation of food in some cafés, meaning that one finds on the menu adjectives like 'local', 'ecological' or 'natural', echoing the global turn towards "the holy trinity of seasonal, organic and local" (Baggini 2014: 29).

The example of café Bella Rosa illustrates the changes in the character of the pop-up event quite vividly. Ten years ago it started as a family café, describing itself as an intimate domestic garden café: 
In a small and cozy home garden we are waiting for you with good coffee, tasty cakes, mushroom pies, [...] grandmother's currant drink, nice company and good spirits. If it rains, we give you shelter next to the rustling fire in the fireplace. If the weather is sunny, you can enjoy the beauty of the flower garden, good music and the adorable smell of roses. (Café Bella Rosa 2007)

By 2013 the concept and image of the café had acquired a more cosmopolitan and professional character:

Bella Rosa is a piece of Italy in the small backyard of a home in Vabaduse Street. [...] guests can enjoy fine Italian music and a nice atmosphere. As a family business, Bella Rosa cares about its family members and café guests. We are equally caring to the workers in coffee, cocoa, tea, and sugar plantations. That's why we use Fairtrade products in our café. In Bella Rosa, you will find le persone in amore, temperamento come italia, un grande menù and la musica bella! (Café Bella Rosa 2013)

In 2013 the personnel consisted of forty people: relatives, neighbours, friends, and friends of friends. Although the garden was well groomed, the overall atmosphere was similar to a mainstream commercial restaurant terrace anywhere in Europe. Despite the efforts of the hosts, the place was overcrowded and the waiters overwhelmed with work. Here, the quiet domestic arena was transformed into a buzzing public space of consumption with professional service. Yet, in some other cases (for example, a nearby vegetarian café) the one-dayentrepreneurs had managed to create a cosy and intimate atmosphere where visitors could sit on kitchen chairs or on a rag carpet on the lawn and feel as though they were visiting a friend. The borders of the home became porous with domestic practices extending into the garden and the stretch of street in front of the house.

Although café organisers are supposed to demonstrate their knowledge of local history traditions, actually few pop-ups serve local traditional food. In 2013 there were two cafés of the kind - Hiiukala fish café, which opened a traditional fishermen's inn at Kärdla harbour (see Fig. 1), and one in a neighbouring village specialising in nineteenth-century food and mixing coastal and small town traditions. This is somewhat surprising, considering that over the last years major initiatives (largely supported by the EU LEADER programme) have been implemented in Hiiumaa with the aim of strengthening ties between local food producers and local consumers, promoting the sustainability of the community and healthy eating through the "from farm to pot" initiative (including the organisation of cooking seminars and workshops, etc.). ${ }^{3}$ 


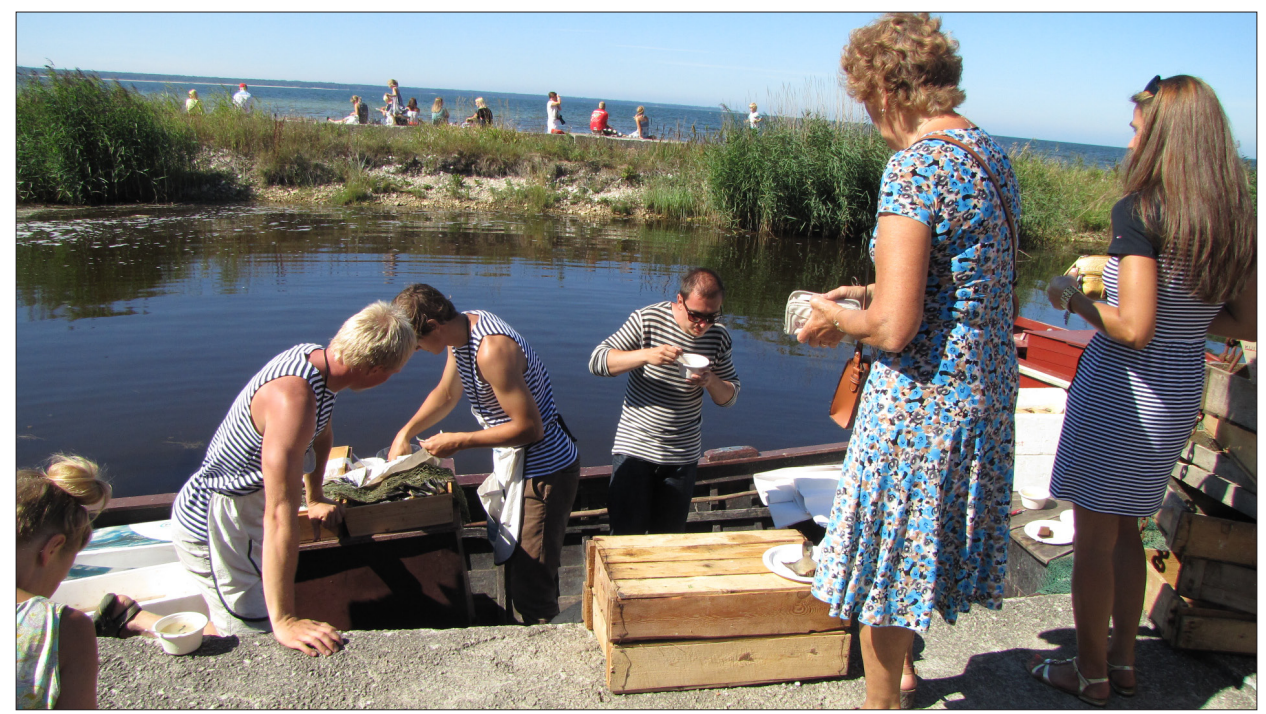

Figure 1. The "fishermen's inn” at Kärdla harbour. Kärdla Café Day, 2 August 2013. Photograph by Ester Bardone.

By the seventh year of the Café Day both the guests and organisers had become aware of the changes in the character of the event. The organisers tried to avoid the overcrowded feeling by scattering the cafés around the town. Yet, most visitors did not enjoy the day in an everyday manner in one café or restaurant; rather, like us, they tried to visit all of them, carefully following the orientation map and tasting a little bit here and there. Therefore, Kärdla was full of 'processions' moving from one attractive spot to another. Public and private spaces were turned into performance stages and united in the spatial structure of a major festival. At the same time the clear focus of the organisers on promoting local heritage and keeping the size, structure and quality of the event under control has prevented the Kärdla Café Day from becoming just another mainstream summer show.

The success of Kärdla has inspired several other communities in Estonia to adopt the same format in order to celebrate local heritage and/or revitalise local community life and attract tourists. ${ }^{4}$ This is part of a global trend of place marketing, in which food plays an important role. Food is used to promote rediscovering and strengthening of the community as well as promoting the place through varied forms of consumption, as is the case with similar (food) festival performances elsewhere in Europe.

The Kärdla Café Day has developed from a spontaneous local initiative into a professionally orchestrated and partly commercialised place-marketing event. Here the pop-up phenomenon has not only extended domesticity into the 
public space, but also brought entrepreneurship into private homes and gardens. The structure and logistics of the event enable the visitors to participate in the creation of a special dynamic and communal spirit in urban spaces. The variety of temporary enterprises gives the clients an opportunity to experience the local milieu and traditions simultaneously with global- and urban-style settings and food.

\section{RESTAURANT DAY IN THE UUS MAAILM DISTRICT}

The Restaurant Day, originally invented in Finland in 2011, is an event intended to promote and celebrate food culture and commensality with no professional or profit intentions. The event has become global, transforming city spaces all over the world four times a year. ${ }^{5}$ The character of the event is anti-bureaucratic and anti-hierarchical; it promotes creativity, cultural diversity, and civic initiative.

In February 2012 an Estonian-Finnish family of artists living in Uus Maailm district near Tallinn city centre was the first to import the Restaurant Day to Estonia, setting up a home restaurant called Savolax in their living room for one day. Apart from the Restaurant Day in Helsinki, they also mentioned other events that promoted organic and local food, home-made goods and recycling as their sources of inspiration. They served Savonian (a historical province in the east of Finland) regional food for about thirty people, mainly people from the neighbourhood, although there were also some visitors from Finland. Since then they have repeated this event a couple of times on restaurant days and during neighbourhood festivals in the back garden of their house. The family was satisfied with the outcome:

Kirsi: In one word, very positive, actually it was quite a hard day, but at the same time it makes you so happy. It gives the energy that pushes you to do it again.

Anu: Not the profit?

Marko: No, rather, in winter we calculated that we did not even get the electricity expenses back, maybe just the food bills. And now in summer it was so that we got most of the expenses covered, but we didn't count our own work.

Kirsi: So it's really rather fun and a hobby at the moment. (Interview on 13 June 2012)

A year after the first Restaurant Day in Helsinki, the Uus Maailm Society, to which Kirsi and Marko belong, introduced the event in their neighbourhood. 
The anti-hierarchical and community-building ethos was clearly voiced by the organisers: "Such enterprises manifest our attitude against bureaucracy and mass consumption" (Interview on 13 June 2012). Some pop-up restaurants were half-illegal; for example, the temporary cafés in the basement and garden of the Uus Maailm Society had no permission to sell alcohol, and the sanitary conditions certainly left to be desired. But one of the main organisers, Erko, stated: "The main aim for us is to have fun" (Interview on 13 June 2012).

As an independent event, the Restaurant Day in Uus Maailm was organised in May 2012 and 2013, later on some pop-up cafés have been opened during the annual district festival in September. When we visited the event in 2012, several pop-up food establishments operated on the borderlands of the public and the private: a street in front of a house, a private garden or backyard, public green areas and new communal spaces like the Uus Maailm garden where herbs and vegetables are grown. In one case, a pop-up café was set up in a first floor flat. In this case visitors did not enter the café; rather, access to food and drink was by climbing a ladder and visitors were served through an open window. Another café sold home-made burgers through a ground floor window. These practices follow the slogan of the Uus Maailm Society: "Home starts in the street". Thus, we are dealing with conscious expansion of homeliness and the blurring of the strict borders between the home and the public space, domesticating common areas. For one day, marginal or impersonal public spaces became arenas in which to celebrate communality and locality (see Fig. 2).

In these pop-up restaurants playfulness and fantasy were important, and the quality of the guests' experience depended on their ability to play along or improvise with the hosts. The pop-up places were mobile both in space and time: one of the cafés opened in a basement and was later moved to the garden; operating times did not correspond to the day's schedule announced on the Restaurant Day Facebook page but were flexible. Opening depended on the time the hosts woke up and when they went shopping for the ingredients; closing time was when the food was sold out or the chefs wanted to take a break.

By ignoring standards of professional planning or service the hosts of popup restaurants emphasised an informal and homely atmosphere. Food seemed to be rather a means of socialising than an aim in itself. From the culinary viewpoint 'nostalgia food' (grandma-style pies and biscuits, hamburgers, Baltic sprat sandwiches with vodka, pancakes) dominated, but there was also exotic food and drink (for example Indian curry, chai) popular among the local young bohemians and spiritually minded guests and New Age fans. However, whereas in Helsinki numerous ethnic minorities were present, introducing their food and culture, this was not the case in Tallinn.

Unlike the annual Uus Maailm Festival, which attracts visitors from all over Tallinn (where pop-up restaurants are one of the many elements of the 


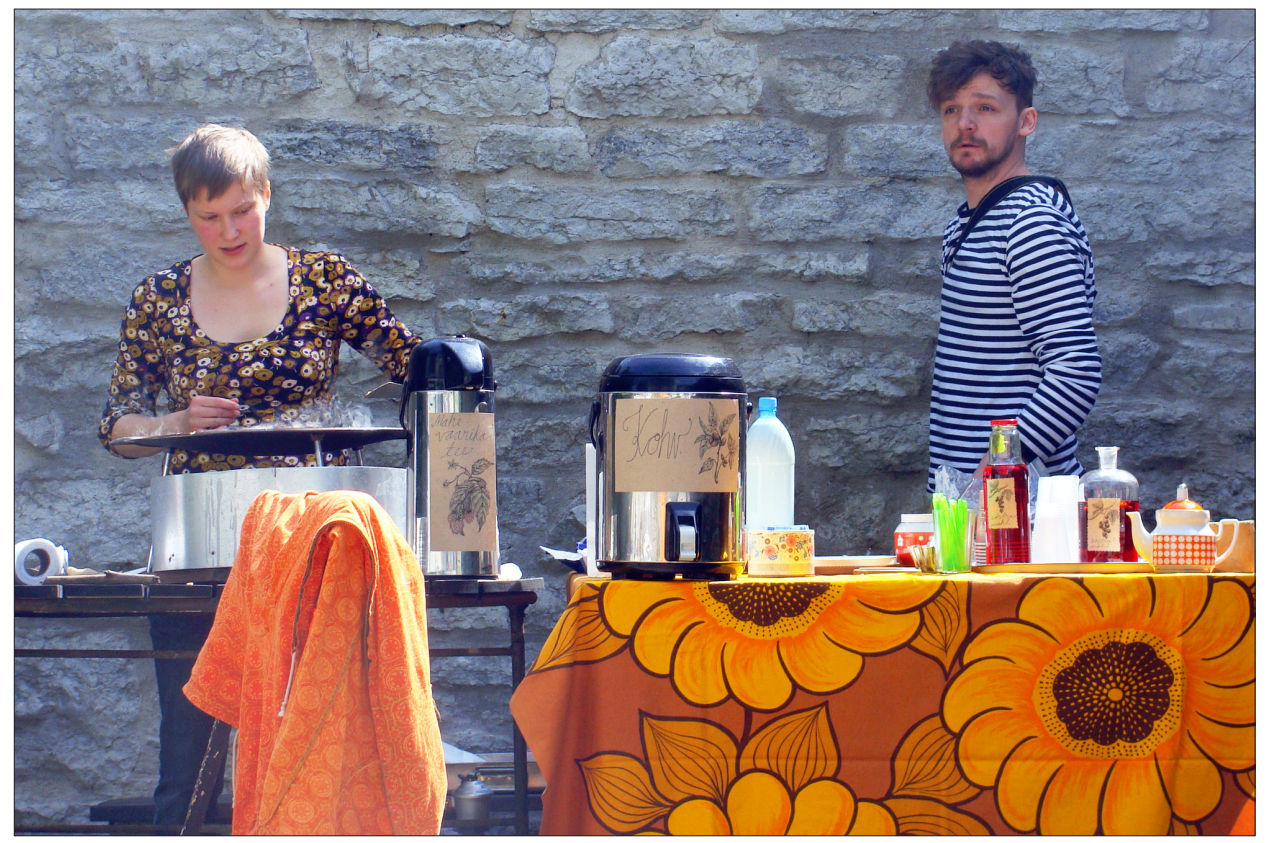

Figure 2. Restaurant Day in the Uus Maailm district. Kirsi and Marko from restaurant Savolax. Tallinn, 19 May 2012. Photograph by Anu Kannike.

event alongside street markets, concerts, playgrounds, etc.), the Restaurant Day mainly attracted younger local families with children. Here, it was specifically the temporary and performative character of restaurants that enabled their hosts to enjoy a different role for one day, contributing to the community building goal. There were no long-term projects associated with these pop-ups:

Kirsi: Yes, to establish a restaurant as a full-time job, then perhaps the joy would vanish. Such a sweet thing and if it became a real job...

Anu: So you prefer the pop-up principle?

Kirsi: Yes, then it would still have the energy, the freshness, like, let's think again what we could do this time. Otherwise, when we did it every day, it might follow very much the same path.

\section{Anu: Routine?}

Kirsi: Yes, routine, then the fresh energy would disappear quicker. We would rather surprise people once. One day is really very good, you work hard one day, and then it's over in a day, and you are happy, at the moment it suits us very well. (Interview on 13 June 2012) 
The bohemian approach to public space as a common 'home', which manifested itself during the Restaurant Day, is not totally unproblematic. Some locals have voiced critical attitudes towards noisy and unruly behaviour in the streets and the lack of control over alcohol consumption during the Restaurant Day, revealing different understandings of the borders of privacy, homeliness, and communality.

Although the Restaurant Day movement has not yet gained wider ground in Estonia, similar temporary food establishments can be seen at community festivals elsewhere. For example, in May 2014-2017 a special Courtyard Café Day was organised during the Kalamaja Days Festival in Tallinn. The spatial structure, idea, and overall atmosphere of the event was very similar to that of the global restaurant days with a detailed orientation map, pop-up restaurants or cafés serving vegetarian or exotic food, support for global or local charity causes, all accompanied by concerts, theatre performances, sports competitions, arts and crafts workshops, and second-hand sales (Hoovikohvikud). Compared with other similar pop-up events, the social and community-building dimension of the event was more pronounced - for example, one café hosted a public discussion on the planning of a local street, some pop-up events collected funds for local jobseekers, and people of all social groups came together for a common dinner, sharing food at a 120-metre table.

All in all, the Restaurant Day in Uus Maailm is an anti-bureaucratic and community-building event that aims to democratise the use of public space and domesticate the streets, parks, and common gardens, etc., through carnivalesque practices. Playfulness and the enjoyment of the participants is of primary importance for the organisers and the main attractive element for visitors. Food underlines the democratic character of the event, offering experience of homemade dishes and more familiar regional cuisines alongside other ethnic tastes. In this case the food serves as a vehicle for social bonding and open commensality rather than an aim in itself - the social experience predominates over the culinary experience and locality is created by people who open their homes to guests, rather than by ingredients and recipes.

\section{TALLINN SUPPER CLUB}

Supper clubs, as mentioned above, are paid dinner parties usually run from somebody's home yet open to everyone who has access to the information about this illegal endeavour. However, in different countries supper clubs may have different local characteristics, being more or less alternative and anti-mainstream. The Tallinn Supper Club is an underground restaurant located in the 
capital of Estonia, which operates mainly from the home of Kristina Lupp, a Canadian native who has Estonian roots and has lived here for the last couple of years. She has worked as a cook in Toronto and Florence and did her master's thesis on the changes in Estonian food culture during the Soviet period. Cooking, travelling, and writing are her passions and the supper club gives an opportunity to share these in many ways, leaving her freedom to keep cooking as a hobby rather than as a profession. "I thought that I don't want to open my own restaurant, but I would like to cook and if it happens once a month, it is not so much work" (Interview on 22 January 2014). Kristina's trips have taken her to a variety of supper clubs in other cities and she was encouraged by her Estonian friend who currently lives in London and runs her own supper club.

The supper club was established in November 2012 and has had regular meetings with some longer breaks. The majority of Tallinn Supper Club events have taken place at the hostess' rented apartment located in an old house in the medieval centre of Tallinn. The rooms have high ceilings and large windows and white walls, furniture in pale green colours provides a neutral backdrop to the events celebrating different food styles. She bought a large white table that sits up to 14 guests. She admits that the lack of a car is one reason why she is not eager to choose other locations; however, some Tallinn Supper Club events have taken place at different venues (for example other restaurants, private residences, etc.). The rule is that the venue is revealed only to the guests who have made a booking and pre-paid a donation for the event. According to Kristina, the place is not what defines the supper club: "If I moved to another apartment, the supper club would move with me" (Interview on 22 January 2014).

Internet and social media are more than just media for feedback; they are the key pillars of the success of any secret supper club - this is how information is spread, clients found, etc. The Tallinn Supper Club has a mailing list that anyone can join; there is also a Facebook account that updates members with news about forthcoming events as well as past dinners (for example, photographs are shared).

Kristina emphasises that, although surrounded by secrecy, the Tallinn Supper Club should not be seen as an exclusive closed club for a limited number of devoted members. She also distinguishes her supper club endeavour from the home restaurant (cf. Võsu \& Kannike 2011):

This supper club, it's like a dinner party. [...] Well, it's not like a home restaurant. It's about a small company at somebody's house. [...] There are some people who always bring me flowers or some small present (laughs). It's weird for me because they have paid, why should they? [...] I think that you have the chance to meet people whom you wouldn't meet otherwise in your daily life. (Interview on 22 January 2014) 
She says that the fact that she usually needs to be busy in the kitchen during the dinner does not bother her and she can get feedback from the guests at the end of the dinner or later on via e-mail. In those supper club events that involve other chefs and locations Kristina sees herself as an intermediary who gives people interested in food a chance to meet culinary professionals face to face.

The Tallinn Supper Club has no standard menus although the hostess has some preferences concerning the cuisine - she loves to cook Italian but also Mexican food, especially because the latter is rare in Estonia. Local food and culinary traditions do not have a primary importance for her, although the Tallinn Supper Club has also hosted an Estonian dinner with top Estonian chef Inga Paenurm, who was also the executive chef to the President of Estonia. Kristina herself praises culinary experiments, interesting flavours and ingredients, and tastes unusual in Estonian mainstream restaurants: "I love to demonstrate to people what ingredients exist. I would like them to taste something new" (Interview on 22 January 2014).

Because of the cosmopolitan and global food styles her ingredients come from Canada, Germany, Sweden - depending on what exactly she wants to cook and what is available. For the local food she visits both indoor and outdoor markets in Tallinn; however, some ingredients are problematic for Estonian producers. Food safety legislation in Estonia means that animal blood cannot be sold in a market, therefore for the Swedish Goose Supper, which includes a spicy black soup (svartsoppa), she had to order the blood from Sweden. Kristina finds this situation absurd, especially because blood is used in many dishes, not least in Estonian traditional dishes (for example, verivorst or blood sausage) (see Fig. 3).

Themes, scripts, and menus for supper club events are also inspired by public holidays, seasonal festivities, and various cultural impulses. For example, the Swedish Goose Supper on 23 November 2013 was triggered by a southern Swedish tradition of eating roast goose in celebration of St. Martin's Day ${ }^{6}$, and by Swedish friends the hostess has in Tallinn. The main course was a roast goose stuffed with apples and prunes and served with red cabbage, Brussels sprouts, and oven-baked Hasselback potatoes. The goose, however, was not from Estonia but from Germany, because Kristina claimed that they could not find the same quality goose meat in Estonia. The event took place in a house belonging to the British ambassador (a personal contact of Kristina's made access possible) with an elegant lobby and a stylish hall designed for dining. To add a more aristocratic touch to the event, porters and waiters were invited for the extra service. There were more than 30 guests who were seated at three tables according to the seating plan, aiming to give people an opportunity to meet somebody they did not know as their neighbour. (However, this plan was not followed fully by all guests.) In spite of the noble venue, the overall atmosphere of the dinner was quite informal, full of conversation around food 


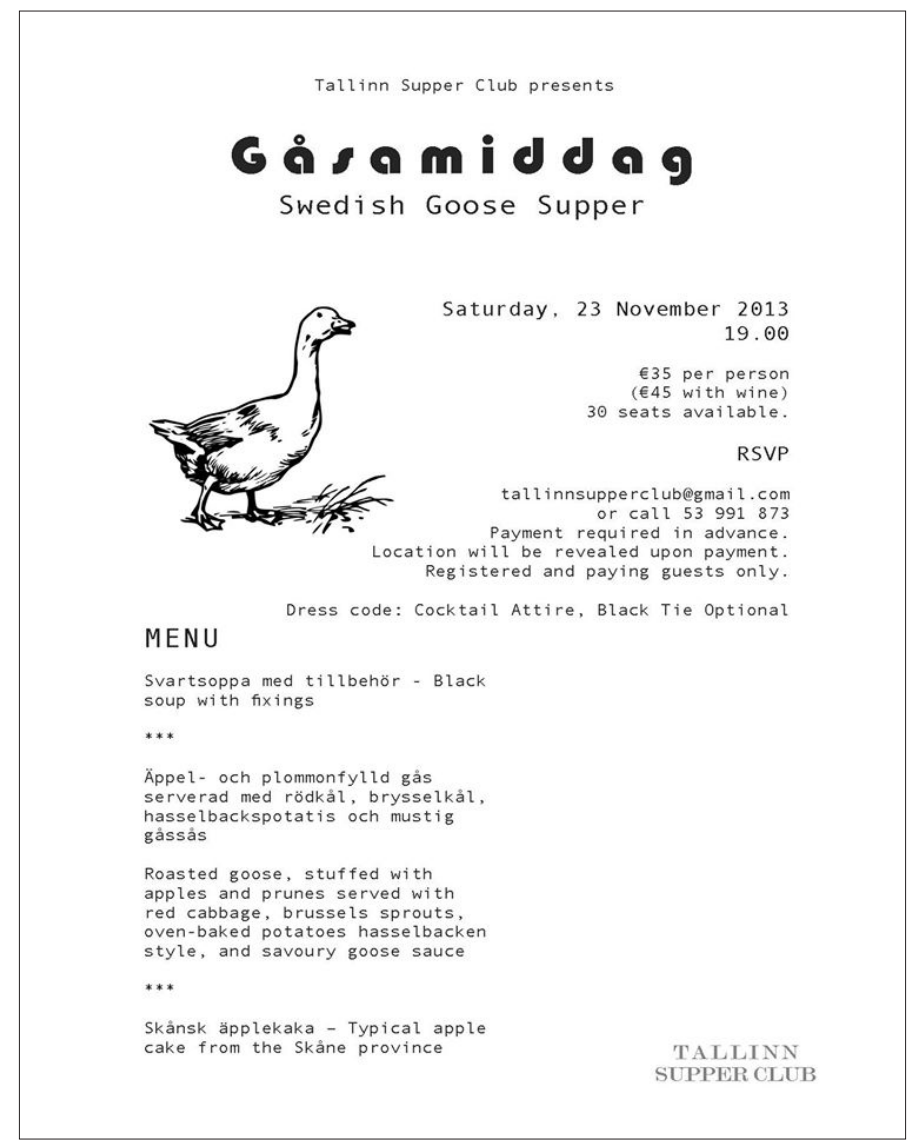

Figure 3. Invitation and menu of the Swedish Goose Supper. Tallinn Supper Club, 2013.

as well as shared personal stories. One of the guest chefs from Sweden shared his colourful memories of food and hospitality in different countries.

Food is an important element of the Tallinn Supper Club events, but from the interview with Kristina it was apparent that she gives significant importance to the commensality and social communication. The Supper Club events are places for social exchange, especially for foreigners living in Tallinn, who form a large number of the permanent visitors to the Tallinn Supper Club. Thus, social communication and interest in shared culinary surprises are the main motivations for both the hostess and the guests. Similarly, the hostess of a Swedish supper club describes her suppers as "social experiments" (Ridderheim 2012: 46), and Hannah Sugarman, the protagonist of the novel The Secret Supper Club, describes the aim of mutual social sharing as being "to swap stories and histories and see how food can bring people together" (Bate 2012: 139). 
Interestingly, the internet and especially social media have not considerably increased the heterogeneity of people who regularly come to the events foreigners dominate among the guests. Perhaps the language is also an issue here because the advertisements, e-mail communication and conversations are usually in English. In that sense the Tallinn Supper Club shares some similarities with other thematic clubs, albeit not exclusively, and also has some traits of the global subculture of foodies, which combines love for food with the search for new experiences and social encounters. The fees or donations for the dinner are relatively high considering Estonians' average income and this may be another reason why the active guests of the supper club dinners are mostly foreigners whose income makes them representatives of the local upper middle class. Such ambivalence between democratisation and distinction, which exists simultaneously in contemporary foodways and foodscapes, sometimes in the context of the same event, is characteristic of a global trend (cf. Jönsson 2013).

Like supper clubs elsewhere, the Tallinn Supper Club may be characterised as a novel phenomenon in the contemporary cosmopolitan urban culture, in which private homes may become subcultural social spaces where food brings people together and enables commensality experiences shared with strangers. Stories about and around food, the intimate atmosphere, and a bit of secrecy are more important here than extraordinary taste experiences.

\section{POP-UP RESTAURANT AT THE ÖÖBIKU GASTRONOMY FARM}

The last pop-up restaurant we introduce is a different, somewhat borderline, example in comparison with the pop-up eating establishments considered above. It was started by professionals with the aim of establishing something permanent, and the choice of a rural venue is in line with the latest trends in Scandinavia, where acknowledged chefs are (re-)establishing destinations for culinary tourism by looking for rural settings that would support the serving of local quality food (see Markowska \& Saemundsson \& Wiklund 2011). However, the temporary restaurant at the Ööbiku Gastronomy Farm enables us to look beyond the boundaries of private and public in the urban context and see how new trends of entrepreneurship and consumption emerge in the countryside.

In the summer of 2013, one of Estonian top chefs, Ants Uustalu, and confectioner Kertu Lukas opened a pop-up restaurant in their home - a recently purchased farmhouse in Kuimetsa village, Rapla County. ${ }^{7}$ The pop-up restaurant opened its doors in July and accepted ten to twenty guests at a time. Although

defined as "pop-up" by the restaurateurs, the business concept was to develop the place into a gastronomy farm in the future - a goal that was realised in 2016. Thus, during the first year, the pop-up restaurant functioned as a liminal 
establishment in order to attract customers and promote the place before the permanent restaurant came into existence. ${ }^{8}$

In 2013 both the restaurateurs were trained professionals with previous work experience in Tallinn. The chef has worked for the President of Estonia, for the Finnish Embassy, and also in upscale London restaurants. The confectioner has, in addition, previous experience in media and public relations, which facilitates knowledgeable marketing of the business. This background gave both Ants and Kertu significant "culinary capital” (Naccarato \& Lebesco 2012) and helped to build up their business in a location far from the city lights. The Gastronomy Farm still needed to be established as an enterprise, therefore in 2013 Ants and Kertu were running catering and cooking courses and also participated actively in open-air festivals and fairs, promoting high-quality Estonian cuisine based on fresh local ingredients. ${ }^{9}$

The host Ants Uustalu has defined the culinary principles and food values of the Öobiku Gastronomy Farm as follows: "quality ingredients, pure and rural tastes, classical culinary techniques and elegant finish" (see Rand 2013: 36). He sees his activity in the context of the current quest for local and authentic food, especially in connection with the Scandinavian developments (cf. Jönsson 2013). Ants believes that good restaurants are moving from cities to the countryside: "Where you have good ingredients, where you can actually grow your food. Then you have bigger profit and better quality. And you are more satisfied with what you are doing" (Interview on 19 August 2013). Kertu adds that having a restaurant at a farm is something "every chef would like to do as a dream job", because it gives an opportunity to earn a living while cooking for small groups - one can be very flexible about the menu (Interview on 19 August 2013). Ants and Kertu agree that for them it is also a lifestyle job because at the Ööbiku Farm they can practice the lifestyle they had been longing for when working in the city - with more freedom and space for themselves.

Ants does not see the gastronomy farm as a farm in the traditional sense where "one drives a tractor and tends large animals". Rather, it is a place where "new tastes are born", where local culinary traditions are rediscovered and reinterpreted and cooking or gardening courses organised (Interview on 19 August 2013). Thus, the Ööbiku Gastronomy Farm is an enterprise that introduces new ideas and practices of rurality (cf. Bardone 2013; Woods 2011). Nevertheless, in 2012 ducks and in 2013 hybrids of wild boar and domestic pigs were kept at Ööbiku. The latter were a great attraction, especially for guests with children who could feed the animals living freely in a hog-pen on the forest floor. In the future the aim is to involve more gardening and to promote it as part of the food culture education for the younger generation.

The pop-up restaurant was set up with a little investment, following the principles of recycling and bricolage. The hosts cleaned a former barn on the farm 
themselves, decorating it in a simple style and furnishing it with secondhand furniture. Kertu expressed her criticism of trendy restaurants with luxurious interiors, where the quality of the food and the efforts of the cook are sometimes underestimated. However, with the help of an investment loan the kitchen at the Ööbiku Gastronomy Farm (located in the main building) has been fully renovated and with its stainless steel surfaces and large cooking island in the middle corresponds to the standards of a professional kitchen, except for the wood-burning stove which is rare in urban restaurants. In the summer season outdoor cooking facilities, such as an underground oven and barbeque, were used to give the wild boar meat and bread a unique smoky taste.

With a few exceptions, the gastronomy farm uses the produce of other farms as locality, ecological production, and genuine taste are the key food values supported at Ööbiku ${ }^{10}$ (Fig. 4). Overall, both the setting and food celebrate a domesticity and simplicity that is given a professional touch through careful selection, preparation, and elegant presentation of the ingredients and dishes. The nostalgia for real tastes plays an important role in their food philosophy. The hosts stressed that they wanted to bring their clients back to forgotten tastes and values. In another interview, Kertu stressed that all food must come from the farm, forest, and bogs: "Old childhood tastes or forgotten things, but adding a bolder and more modern twist. For example, smoked duck eggs, apple tree smoked salmon, dandelion syrup or salad, nettle, oxalis or wild mushroom dishes..." (Rosen 2012). On the website of their enterprise, Ants declares that his aim is to "surprise clients with the luxurious simplicity you might still recall as the green grass and blue sky of childhood when not every soup was seasoned with a bouillon cube or every piece of fish with lemon pepper" (Ööbiku, emphasis added).

Social media has played quite an important role in marketing the business as their main target group in 2013 seemed to be (urban) people from their own generation or slightly older - people in their thirties and forties. ${ }^{11}$ The Ööbiku Facebook account was likewise used to inform guests about the dates and availability of dinners and lunches and to share visual information about the dishes or other events at which the chefs participated. The word was spread quickly and with the help of Facebook the dinner tables were usually booked well in advance.

However, not all of their customers are dedicated urban foodies: there have also been visitors from smaller places. The location in the vicinity of Tallinn makes it easy to get back to the city by evening without the need to look for accommodation (in the future the gastronomy farm wants to provide farmstyle lodging). Yet, the locals (except a biodynamic farmer who also originates from Tallinn) were rather sceptical about the idea of a restaurant in a former barn - "Who would come to eat here?" (Interview on 19 August 2013). Some local people involved in the catering business were also afraid of losing their 


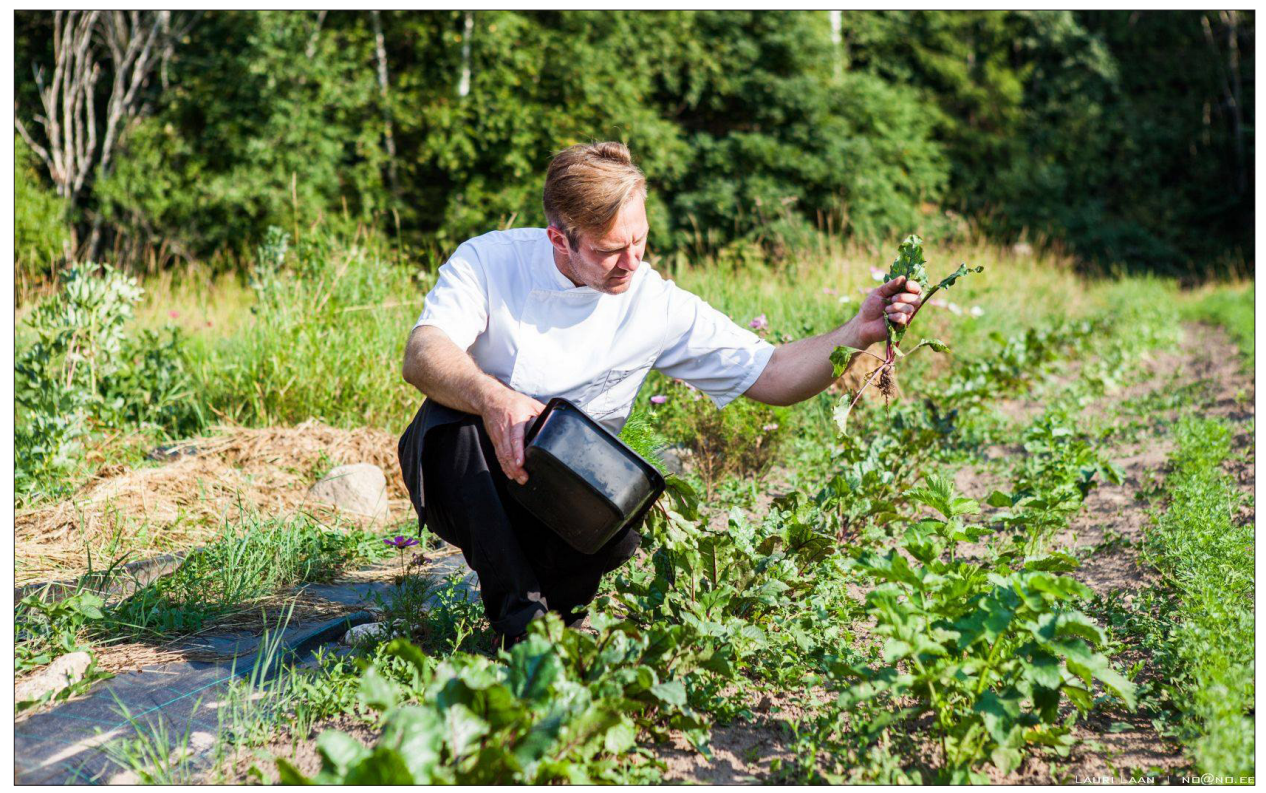

Figure 4. Ants Uustalu, chef de cuisine of the Ööbiku Gastronomy Farm. Kuimetsa, 2014. Photograph from Facebook, Ööbiku Gastronomy Farm.

business to the distinguished chefs, but the hosts of Ööbiku sorted this out early on - they did not aim to deal with the catering of local parties and festivities, except for a few annual events that enable them to feel part of the community. Now locals often call them to provide home-grown vegetables or fruits. All in all, the contribution of the enterprise to the local community is somewhat ambivalent - the ingredients come from the region, but the clients are mainly well-off city people.

The pop-up restaurant at the Ööbiku Gastronomy Farm challenges the borders between city and countryside and is an example of rural gentrification, combining the village milieu and carefully selected local ingredients with gourmet cooking and service. By hosting guests in their private home at a farm, the chefs emphasise the values of being local, purity, and simplicity through a rustic domestic setting, at the same time underlining the exclusivity of such food by their professional input and relatively high prices. Yet, the pop-up restaurant at the Ööbiku Gastronomy Farm likewise challenges the borders between temporary and permanent - since autumn 2014 the restaurant is open all year round, from Wednesday to Sunday, for pre-booked clients, but Ants continues to be the only chef in the house. The novelty and ephemerality of pop-up dining have vanished, having been supplanted by consistent quality and high reputation (in 2014-2017 the Ööbiku Gastronomy Farm was among the 50 best restaurants in Estonia). 


\section{CONCLUDING DISCUSSION}

The temporal quality expressed in the term 'pop-up restaurant' does not mean that we have a mere substitute for a 'real' enterprise. Instead, relying on our examples, we suggest that it has extra qualities permitting many things that would be impossible in the long term. Such temporary urban or rural restaurants are dynamic spaces allowing for innovation and experimentation for both lifestyle entrepreneurs and consumers.

Like the setting and the menu, the sensory elements of the atmosphere in pop-up restaurants are not fixed, but of transitory character, allowing the hosts to employ their creativity in diverse ways and provide a multitude of new restaurant experiences. The possibility to communicate and advertise through social media in a fast and flexible manner adds to the ephemerality and exclusivity of the pop-up dining experience, but also enables the customers to give immediate feedback and thus contribute to the development of such events.

There are multiple pop-up restaurants in Estonia, some of which are more focused on culinary, and some on social, experiences. Generally speaking, they entail anti-mass-consumption attitudes and celebrate people's creativity. As Estonian food culture is becoming more and more hybrid, pop-up restaurants reflect global trends on the gourmet foodscape - an increased attention to environmental consciousness, local specialities and authentic experiences as opposed to industrial or mainstream restaurant food. The pop-up restaurant scene in Estonia is quite diverse, in this being similar to that of other countries, and the material we studied enables us to suggest a preliminary typology:

(1) pop-up community events and shared or commoditised hospitality and commensality;

(2) pop-up cafés and restaurants organised by professional cooks or other food experts in order to gain more control over ingredients, menu, and setting;

(3) supper clubs as an introduction of a global format that is currently a limited phenomenon for small groups of foodie customers.

Indeed, such a classification just indicates some main aims and functions that a pop-up restaurant may have, as its more specific characteristics depend on the particular socio-cultural context in which it emerges. There are no two identical pop-up eating establishments and by definition it is impossible to step into the same pop-up restaurant twice.

The pop-up restaurant, along with other pop-up enterprises, has brought new dynamics to urban and rural public and private spaces. Parts of public spaces have been privatised or domesticated to express individuality and offer intimate social encounters; at the same time some private spaces have been involved in wider public initiatives of community or neighbourhood building, 
promoting social cohesion and marketing localities. Thus, pop-up restaurants produce liminal spaces in habitual everyday environments.

In contemporary cities the formation of distinctive neighbourhoods is a way of giving a certain flavour to public spaces as spaces of sociability. This often runs parallel to the rise of environmental awareness and a search for sustainable urban forms where "impersonal urban space can be broken into interpersonal spheres of communities" (Madanipour 2003: 209). The pop-up restaurants in some new urban neighbourhoods contribute to the creation of the temporary communitas through non-habitual use of space and common eating experience among people who usually do not meet each other.

In the cases studied, it is not so much particular food styles that define a pop-up restaurant - although some chefs may take their job very seriously but rather values related to creative economy and alternative consumption that matter. Some authors have claimed that supper clubs especially are manifestations of resistance to corporate restaurant culture. One radical supper club owner in the US states that supper clubs are "alternatives to the restaurant industry and its ultra-capitalist, ultra-exploitative, ultra-wasteful trappings" (Kennedy 2008). Although this is not always the case in Estonia, the pop-up restaurants studied are seeking alternatives to mainstream food consumption often providing more local and personalised dining experiences. There is also a significant resistance to mainstream food consumption in which the authenticity of culinary and social experiences is believed to have vanished.

Some of our examples support the observation made by Greg Richards, who claims that food experiences "contribute to local development in a range of ways, stimulating cultural production and consumption and supporting regeneration in urban and rural settings" (Richards 2012: 25). In addition, pop-up restaurants may contribute to the experience of locality not in terms of food but in terms of social experience, through immediate encounters between the host and guests.

'Homely' food, atmosphere, and service are used for both community building and as an added value in the commodified experience economy (Jönsson 2013). Contemporary foodies are ready to pay extra for the unique setting and/ or company. They value time-limited exclusivity and performance-like immediate encounters that may increase the feeling of authenticity of the consumption experience. On the other hand, pop-up restaurants set up in private homes illustrate the tendency that the contemporary home is no longer an enclosed and clearly demarcated space - instead it is in continuous interaction with the outside world, and parts of the home may be transferred into public spaces either through commercial or pop-up activities (Johansson \& Saarikangas 2009: 11; cf. Miller 2001; Võsu \& Kannike 2011).

By extending the borders of the conventional restaurant or home into public space, pop-up restaurants create spaces of negotiation between the private and 
the public and new forms of communality. The liminal properties and heterogeneous multisensory experience make them attractive for both entrepreneurs and consumers. Thus, the new wave of temporary activities, including pop-up restaurants, might have deeper implications not only for personal creativity and community-building, but also wider spatial policy and practice. Pop-up dining demonstrates the importance of individuals as creative cultural agents who cook as well as eat.

\section{ACKNOWLEDGEMENTS}

This research was supported by Estonian Research Council grant IUT 34-32, "Cultural heritage as a socio-cultural resource and contested field", and the European Union through the European Regional Development Fund grant 2014-2020.4.01.16-0049, "Competitive research in the academic fields of responsibility of the Estonian National Museum".

\section{NOTES}

1 Historically the term 'supper club', especially in the USA, designated closed clubs for entertainment as well as dining that became popular in the 1930s (see Hoekstra 2013).

2 For example, the charitable pop-up shop Mondo sells handmade items from Africa and Afghanistan (Mondo pop-up pood) and a pop-up café run by Estonians in Uganda employs people with special needs (Pop Up Kampala). The concept 'pop-up' has also been used for temporary multidisciplinary art projects, for example, the pop-up exhibition "27" set up in Tartu city centre during the annual drama festival and featuring "ideas, thoughts and magical spaces" of Estonian scenic designers (Kakskümmend seitse). In February 2014 the first pop-up museum in Estonia opened for two weeks in the Telliskivi Creative City in Tallinn (Telliskivi pop-up museum) and a pop-up restaurant led by Ants Uustalu from Ööbiku farm in an art gallery served as a meeting place and club for Tallinn Music Week, a festival of contemporary music (TMW Tastes).

${ }^{3}$ See in detail in Hiidlaste Koostöökogu, Growing Gastronauts.

4 For example, the organisers were invited to Värska in order to train local people to set up a similar event. On 17 August 2013, the Seto Külavü̈̈ Kostipäiv (Seto Belt of Villages Treats Day) featured ten cafés in farmyards and farmhouses. Although the event promoted local Seto food (fish, different pies, the local cottage cheese sõir, etc.) and the ingredients were of local origin, the style of these pop-ups, from names to entertainment programmes, was borrowed one-to-one from the Kärdla example (Kostipäiv).

5 One-day restaurants have so far popped up in more than 70 different countries (see http://www.restaurantday.org/en/).

6 St. Martin's Day was traditionally celebrated in Estonia. Some domestic animals were slaughtered in order to celebrate the end of the harvest season. Estonian folk dishes included pig's head with vegetables; also various blood dishes were served. The custom to eat goose is quite recent and was mainly practiced by the wealthier families. 
7 Approx. 60-70 km from Tallinn, the largest city in Estonia.

8 Although small rural eating establishments have a long history in Estonia, a gourmet restaurant established in a rural setting has become a relatively recent trend in the modern culinary landscape related to the ongoing commodification and gentrification of the modern countryside (cf. Norrman \& Pettersson 2011; Markowska \& Saemundsson \& Wiklund 2011). There is a venue similar to Ööbiku in southern Estonia - the Tammuri Farm Restaurant, run by an amateur chef. The principle of both restaurants is not to offer a standard menu and opening hours but to provide seasonally inspired dishes and accept only those guests who pre-book their visit (see Võsu \& Kannike 2011).

9 Similar examples of pop-up restaurants promoting local food and local ingredients are, for example, the Chamber of Taste Experience and the Community Kitchen of Peipsimaa in St. Anthony's Yard in Tartu.

${ }^{10}$ In this sense they are quite different from the farm restaurant at the Ängavallen Farm in Sweden (see Ängavallen).

11 The website was built with the help of a professional webmaster and photographer.

\section{REFERENCES}

Baggini, Julian 2014. The Virtues of the Table: How to Eat and Think. London: Granta. Bardone, Ester 2013. My Farm is My Stage: A Performance Perspective on Rural Tourism and Hospitality Services in Estonia. Dissertationes ethnologiae Universitatis Tartuensis 4. Tartu: University of Tartu Press. Available at http://dspace.ut.ee/ bitstream/handle/10062/34504/bardone_ester.pdf?sequence=1, last accessed on 10 January 2018.

Bate, Dana 2012. The Secret Supper Club. London: Constable \& Robinson.

Bishop, Peter \& Williams, Lesley 2012. The Temporary City. London \& New York: Routledge.

Fernandes, Kasmin \& Sharma, Supriya 2013. Culture Goes Pop-Up. The Times of India, 20 January. Available at http://timesofindia.indiatimes.com/life-style/people/ Culture-goes-pop-up/articleshow/18099810.cms, last accessed on 5 January 2018.

Harris, Ella 2014. Exploring Time-Space in the Temporary City. Landscape Surgery, 25 July. Available at http://landscapesurgery.wordpress.com/2014/07/25/ exploring-time-space-in-the-temporary-city/, last accessed on 5 January 2018.

Hoekstra, Dave 2013. The Supper Club Book: A Celebration of a Midwest Tradition. Chicago: Chicago Review Press.

Johansson, Hanna \& Saarikangas, Kirsi (eds.) 2009. Homes in Transformation: Dwelling, Moving, Belonging. Helsinki: Suomalaisen Kirjallisuuden Seura.

Johnston, Josée \& Baumann, Shyon 2010. Foodies: Democracy and Distinction in the Gourmet Foodscape. New York \& London: Routledge.

Jönsson, Håkan 2002. Matupplevelser. [Food Experience.] In: Thomas O'Dell (ed.) Upplevelsens materialitet. Lund: Studentlitteratur, pp. 55-71.

Jönsson, Håkan 2013. Chef Celebrities, Foodstuff Anxieties and (Un)Happy Meals: An Introduction to Foodways Redux. Ethnologia Europaea, Vol. 43, No. 2, pp. 5-16.

Kennedy, Elizabeth 2008. Dining Off the Grid. The Monthly: The East Bay's Premier Magazine of Culture and Commerce, March. Available at www.themonthly.com/ feature-03-08-1.html, last accessed on 5 January 2018. 
Kurik, Kaija-Luisa 2013. Temporary City: Critical Approach to Temporary Urbanism, Temporary Use and the Idea of Temporary in a City: Four Case Studies from Tallinn. Diss. (Master's Thesis). Estonian Academy of Arts.

Löfgren, Orvar \& Willim, Robert 2005. Magic, Culture and the New Economy. Oxford $\&$ New York: Berg.

Lugosi, Peter \& Bell, David \& Lugosi, Krisztina 2010. Hospitality, Culture and Regeneration: Urban Decay, Entrepreneurship and the "Ruin" Bars of Budapest. Urban Studies, Vol. 47, No. 14, pp. 3079-3101. http://dx.doi. org/10.1177/0042098009360236.

Madanipour, Ali 2003. Public and Private Spaces of the City. London \& New York: Routledge.

Markowska, Magdalena \& Saemundsson, Rögnvaldur J. \& Wiklund, Johan 2011. Contextualising Business Model Development in Nordic Rural Gourmet Restaurants. In: G. A. Alsos \& S. Carter \& E. Ljunggren \& F. Welter (eds.) The Handbook of Research on Entrepreneurship in Agriculture and Rural Development. Cheltenham: Edward Elgar Publishing, pp. 162-179.

Miller, Daniel 2001. Behind Closed Doors. In: D. Miller (ed.) Home Possessions: Material Culture Behind Closed Doors. Oxford \& New York: Berg, pp. 1-19. Available at https://is.muni.cz/el/1423/jaro2017/SAN107/um/Miller_Home_Possessions.pdf, last accessed on 10 January 2018.

Naccarato, Peter \& LeBesco, Kathleen 2012. Culinary Capital. London \& New York: Berg. Noorani, Tehseen \& Blencowe, Claire \& Brigstocke, Julian (eds.) 2013. Problems of Participation: Reflections on Democracy, Authority, and the Struggle for Common Life. Lewes: Authority Research Network.

Norrman, Michaela \& Pettersson, Lars 2011. Gourmet Restaurants and Small-Scale Food Production: Swedish Rural and Urban Regions. 50th Congress of the European Regional Science Association: Sustainable Regional Growth and Development in the Creative Knowledge Economy, 19-23 August 2010, Jönköping, Sweden. Available at http://www-sre.wu.ac.at/ersa/ersaconfs/ersa10/ERSA2010finalpaper1664.pdf, last accessed on 5 January 2018.

Pine, B. Joseph \& Gilmore, James H. 1999. The Experience Economy: Work Is Theatre \& Every Business a Stage. Boston: Harvard Business School Press.

Põllo, Helgi 2010. Vaimse kultuuripärandi kaardistamisest Hiiumaal. [Mapping Intangible Heritage in Hiiumaa.] Available at http://pk.rmk.ee/parandkultuur/25.03.10_ tartu/p6llo_est.pdf, last accessed on 5 January 2018.

Põllo, Helgi \& Kokovkin, Toomas 2007. Saarelisus ja saare identiteet. [Islandness and Island Identity.] Raadio Ö̈̈̈̈likool. Available at http://heli.er.ee/helid/oy/ OY2007_Helgi_Pollo_ja_Toomas_Kokovkin_Saarelisus_ja_saare_identiteet.mp3, last accessed on 5 January 2018.

Pulk, Kadri 2007. Kärdla koduaiad, muuseumid ja raudlaevad pakuvad täna kohvi. [Homeyards, Museums, and Iron Ships in Kärdla TreatYou to Coffee Today.] Eesti Päevaleht, 3 August. Available at http://epl.delfi.ee/news/eesti/kardla-koduaiad-muuseumidja-raudlaevad-pakuvad-tana-kohvi.d?id=51096066, last accessed on 5 January 2018.

Rand, Jana 2013. Gastronoomiatalu luksuslik lihtsus. [Luxurious Simplicity of a Gastronomy Farm.] Maakodu, No. 3, pp. 36-39. Available at http://www.digar. ee/arhiiv/et/perioodika/37396, last accessed on 10 January 2018.

Rapport, Nigel \& Overing, Joanna 2000. Social and Cultural Anthropology: The Key Concepts. London \& New York: Routledge. 
Richards, Greg 2012. An Overview of Food and Tourism Trends and Policies. Food and the Tourism Experience: The OECD-Korea Workshop. N.p.: OECD Publishing, pp. 13-46. http://dx.doi.org/10.1787/9789264171923-3-en.

Ridderheim, Karin 2012. Restaurang $i$ vardagsrummet: En kvalitativ undersökning av fenomenet middagsklubbar. [Restaurant in the Living Room: A Qualitative Research of Supper Clubs.] Kandidatuppsats. Uppsala Universitet. Available at http://uu.diva-portal.org/smash/get/diva2:530321/FULLTEXT01.pdf, last accessed on 10 January 2018.

Rodgers, Kerstin 2011. Supper Club: Recipes and Notes from the Underground Restaurant. London: Harper Collins.

Rosen, Britt 2012. Tegus paar ööbikuid. [An Efficient Couple on Ööbiku Farm.] Postimees, 10 June. Available at http://www.naine24.ee/869468/tegus-paar-oobikuid, last accessed on 5 January 2018.

Rudi, Hanneli 2013. Mandrirahvas vallutas Kärdla õued. [Mainland People Occupied Yards in Kärdla.] Postimees: Tarbija 24, 5 August. Available at http://www. tarbija24.ee/1321632/mandrirahvas-vallutas-kardla-oued, last accessed on 5 January 2018.

Russo, Maria Teresa 2012. Home, Domesticity and Hospitality: A Theoretical Reflection. Hospitality \& Society, Vol. 2, No. 3, pp. 309-320. http://dx.doi.org/10.1386/ hosp.2.3.309_1.

de Solier, Isabelle 2013. Food and the Self: Consumption, Production and Material Culture. Materializing Culture. London \& New York: Bloomsbury.

Tyler, Alison 2009. Everyone Back to Mine: Pop-Up Restaurants in Private Homes Are the Latest Foodie Fad. The Independent, 3 June. Available at http://www. independent.co.uk/life-style/food-and-drink/features/everyone-back-to-minepopup-restaurants-in-private-homes-are-the-latest-foodie-fad-1696262.html, last accessed on 5 January 2018.

Võsu, Ester \& Kannike, Anu 2011. My Home Is My Stage: Restaurant Experiences in Two Estonian Lifestyle Enterprises. Journal of Ethnology and Folkloristics, Vol. 5, No. 2, pp. 19-47. Available at https://www.jef.ee/index.php/journal/article/ view/92, last accessed on 10 January 2018.

Williams, Zoe 2009. The Secret Feast. The Guardian, 10 February. Available at http:// www.theguardian.com/lifeandstyle/2009/feb/10/underground-restaurants-london, last accessed on 5 January 2018.

Woods, Michael 2011. Rural: Key Ideas in Geography. London \& New York: Routledge. Zukin, Sharon 1991. Landscapes of Power: From Detroit to Disney World. Berkeley \& Los Angeles \& London: University of California Press.

\section{INTERNET SOURCES}

Ängavallen. Available at https://angavallen.se/en/, last accessed on 18 January 2018.

Café Bella Rosa 2007 = Café Bella Rosa. Hiiumaa kohvikutepäevad. [Café Days in Hiiumaa.] Available at http://kohvikutepäev.ee/aastakaigud/2007/cafe-bella-rosa/, last accessed on 8 January 2018.

Café Bella Rosa 2013 = Bella Rosa. Hiiumaa kohvikutepäevad 2013. [Café Days in Hiiumaa 2013.] Available at http://kohvikutepäev.ee/en/2013/cafes/bella-rosa/, last accessed on 8 January 2018. 
Growing Gastronauts = Sirguvad söögisellid. [Growing Gastronauts.] Available at http:// hiiusellid.webnode.com/, last accessed on 5 January 2018.

Hiidlaste Koostöökogu = Kohalik toit. [Local Food.] MTÜ Hiidlaste Koostöökogu. Available at http://www.kogu.hiiumaa.ee/index.php?page=kohalik-toit, last accessed on 8 January 2018.

Hiiumaa kohvikutepäevad. [Café Days in Hiiumaa.] Available at http://kohvikutepäev. ee/, last accessed on 10 January 2018.

Hoovikohvikud = Kalamaja päevade hoovikohvikud. [Yard Cafés on Kalamaja Days.] Available at http://kalamajapaevad.ee/hoovikohvikud/, last accessed on 18 January 2018.

Kakskümmend seitse $=$ Draama 2013 blogi. [Drama 2013 Blog.] September 7. Available at http://etfestival.wordpress.com/2013/09/07/kakskummendseitse/, last accessed on 10 January 2018.

Kärdla kohvikutepäev. [Kärdla Café Day.] Available at https://www.facebook.com/ kohvikutepaev, last accessed on 10 January 2018.

Kohvilähkrid = Hiiumaa kohvikutepäevad: Kohvilähkrid. [Café Days in Hiiumaa: Coffee Pots.] Available at http://kohvikutepäev.ee/kohvilahkrid, last accessed on 8 January 2018.

Kostipäiv = Seto Külävüü kostipäiv 17. augustil. [Seto Belt of Villages Treats Day on 17 August.] Visitvoru.ee. Available at http://www.visitvoru.ee/uudised/setokulavuu-kostipaiv-17-augustil/, last accessed on 8 January 2018.

Mondo pop-up pood. [Mondo Pop-Up Shop.] Available at https://www.facebook.com/ mondopood, last accessed on 10 January 2018.

Ööbiku = Ööbiku gastronoomiatalu. [Ööbiku Gastronomy Farm.] Available at http:// www.oobiku.ee/meist, last accessed on 9 January 2018.

Pop-Up City. Available at http://popupcity.net/about/\#ixzz2hJc0iVBQ, last accessed on 10 January 2018.

Pop Up Kampala = Estonian World: Estonians Popping Up in Uganda: The Story of Pop Up Kampala. Available at http://mondo.org.ee/en/estonian-world-estonians-poppingup-in-uganda-the-story-of-pop-up-kampala-2/, last accessed on 10 January 2018.

Restaurant Day. Available at http://www.restaurantday.org/en/info/about/, last_accessed on 10 January 2018.

Telliskivi Pop-Up Museum. Available at http://telliskivimuuseum.weebly.com/eng.html, last accessed 10 January 2018.

TMW Tastes = Tallinn Music Week Tastes: Restaurants. Available at http://2017. tallinnmusicweek.ee/festival/tastes/restaurants/index.html, last accessed on 10 January 2018.

\section{FIELDWORK SOURCES}

Interview with Kirsi Miettinen and Marko Ausma, Tallinn, 13 June 2012. Transcript at the authors' disposal.

Interview with Erko Valk, Tallinn, 13 June 2012. Transcript at the authors' disposal.

Interview with Kertu Lukas and Ants Uustalu, Kuimetsa, 19 August 2013. Transcript at the authors' disposal.

Interview with Kristina Lupp, Tallinn, 22 January 2014. Transcript at the authors' disposal. 